\title{
Interferences of Bandung Creative City in Developing the Creative Economy of Bandung City
}

\author{
Mohamad Ichsana Nur'1, Roy Valiant Salomo ${ }^{2}$, Khaerul Umam³ , Siti Alia ${ }^{4}$ \\ ${ }^{1}$ Department of Public Administration Faculty of Social and Political Science, Sunan Gunung Djati Bandung State \\ Islamic University (email: mohamadichsana22@uinsgd.ac.id), ${ }^{2}$ Department of Public Administration Faculty of \\ Administrative Science, University of Indonesia (email: royvsalomo2357@gmail.com), ${ }^{3}$ Department of Public \\ Administration Faculty of Social and Political Science, Sunan Gunung Djati Bandung State Islamic University \\ (email: umam@uinsgd.ac.id), ${ }^{4}$ Department of Public Administration Faculty of Social and Political Science, Sunan \\ Gunung Djati Bandung State Islamic University (email: aliaalya267@yahoo.co.id)
}

\begin{abstract}
This present research aims to analyze the interferences of the Bandung Creative City Forum (BCCF) as a representative of creative economy communities in the development of creative economy in the City of Bandung. This research is descriptive research with post-positivist approach and used in-depth interviews as well as document studies as the data collection methods. The results show that the BCCF as an independent societal organization concerned with the development of creative economy in the City of Bandung was able to run a number of internal and external activities effectively and made physical and social contributions directly felt by citizens and the city. However, the BCCF is faced with the reality that in the meantime, they are utterly different from they were in the forgoing two periods. For this reason, the BCCF is striving to adapt with their needs in the present time while keeping on carrying out their previous positive activities, especially those directly linked with the citizens of the City of Bandung.
\end{abstract}

\section{Keywords:}

civic engagement; community participation; community empowerment; society-political governance; creative economy

\section{Introduction}

With the improvement of the community's life emerges newer, more varied governance concept meanings (Rhodes, 1997: 46). Currently, governance is experiencing a significant shift in view, in that it is more focused on the fulfillment of public goals by government and non-government actors (Chhotray and Stoker, 2009: 16). Under such conditions, the term governance has led to the shift in the government's roles in governing and managing a state (Kooiman, 2003:3; Pierre and Peters, 2005:3). Governance today is a product of self-organizing networks and interdependence between one actor and another (Rhodes, 1997: 53). This new definition of governance is a redefinition of the role of the communities, who initially only serve as passive users of government services but transform into entities playing a prominent role and demonstrating active participation, in the governance process of their affairs in accordance with their needs and problems (Lappe \& 
Dubois, 1994; Steen-Johnsen, et al, 2011:557; Bernauer and Betzold, 2012:63). In other words, this new governance meaning recognizes the community's capacity to deal with their own affairs without being fully reliant on the power of the government, who can exert their authority (Stoker, 1998: 18; Chhotray and Stoker, 2009: 20-21).

The increasingly diversified, complex and dynamic lives of the community require the engagement and participation of multiple actors from non-governmental organizations (NGOs) as part of the community (Kooiman, 2003: 162). For these multiple actors and entities to be connected, and to communicate, with each other, interaction comes out as something worth attention. To distinguish the "new" form of interaction between the government and the community separately or collectively, Kooiman (1993: 1-2) refers to it as society-political governance.

Interaction is defined in a simple term as mutual influence between two or more political and social entities (individuals, societal organization, public institution) (Kooiman, 2003: 13). Interaction assumes a central position within the societal governance for two reasons. The first reason is that the term societal governance is an expression of the assumption that "without social governance, political governance will not exist, and vice versa," rendering the interaction between social entities and political entities critical from the governance perspective. The second reason is that no single social or political actor has the knowledge and information required to solve public and private issues that are complex, dynamic and varied, thus interaction comes to be an effective way and a strong synthetic and analytical power in the face of such societal phenomena (Kooiman, 2003: 24). As such, Kooiman (1993: 38) has explained that the social-political system dynamics can in no way be understood without the knowledge on the interaction concept, whereas interaction can in no way be understood without the knowledge on interaction types that differ by context. One of interaction types is interferences.

Interferences can be regarded as a relatively inclusive, flexible and spontaneous interaction process that takes place within and around the activities of a social entity. This type of interaction is commonplace within a community group, making it frequently attached to self-governance way of interaction. Self-governance is the capacity of a social entity that has an initiative to govern itself according to its ability and to develop and maintain its identity, enabling them to display the highest level of autonomy. It is essential 
to note that in order to maintain and expand such an autonomous organization, it is necessary to have individual capacity and to implement the organization's values (Kooiman in Grote and Gbikpi, 2002: 83). Accordingly, to make it easy to collect and analyze data of this research, we outline the following indicators: a) the organization actors meet up and discuss a social issue on a regular basis (Kooiman, 2003: 85); b) the organization leader motivates his members (p. 68); c) the organization actors are capable of designing and organizing an activity (p. 80); and d) the organization actors make a social movement on his own initiative (p. 178).

In the present research, we focused on the development of creative economy in the City of Bandung as a public affair with community-initiated activities. Creative economy development in and of itself refers to the development of economic activities based on individual creativity, skills and talents to create the power of individual creativity that has economic values and influence on the community's welfare (Presidential Instruction Number 6 of 2009 on Creative Economy). As a derivation, it appears that the City of Bandung should autonomously establish a policy on creative economy development as a response to its considerable potential as a model creative city at the national level (The Ministry of Trade, 2009; The Ministry of Tourism and Creative Economy, 2013) and the global level in UNESCO version (http://en.unesco.org, 2017).

The success of the City of Bandung to be a model creative city nationwide and worldwide is by virtue of the efforts of all stakeholders, including the government, private entities and community. Notably, as stated by an expert from the Creative Economy Body, creative economy communities play a more significant role in comparison to other entities in paving the way for Bandung to become a creative city (Ramalis in an interview, May 12, 2018). They are equipped with high creativity, high ability to use information technology and outstanding work ethic. More importantly, rather than individually, they work and conduct activities collectively in a community. They are fully aware that the silih asah, silih asih and silih asuh (i.e. to remind each other, to be affectionate toward each other and to guide each other) values have been engraved as their life identity, in that the values of togetherness and mutual cooperation have become an integral part of the conduct of creative economy activities in the city. 
According to a review, it was figured out that there were 3,200 creative economy communities in the City of Bandung spread over 16 creative economy sub-sectors (Head of Creative Economy Division of the City of Bandung in Rakyat Merdeka Online, April 8, 2017). However, out of such large number, only 122 were officially registered. One of the communities, the Bandung Creative City Forum (BCCF), serves as a creative societal organization that initiated and catalyzed the process of Bandung becoming a Creative City. The Chairman of the Committee of Creative Economy of the City of Bandung stated in an interview (March 28, 2018) as follows:

"...The BCCF was the initiator in the incorporation of the City of Bandung into the UNESCO World Creative City networking. The BCCF believed that if it successfully enters the network, this will become a bargaining power showing the government that if a community is able to break through the world class, it should have been much reasonable if the government shows support. Even if we were not recognized by the UNESCO, at the very least we have collected data that we are a creative city in our own way. Otherwise, we would be seen as only talk."

The statements above can be interpreted as an acknowledgment that by far, the BCCF as a social entity has successfully demonstrated its capacity and role in the development of creative economy in the City of Bandung. This research spotted that the potential of creative economy development in the City of Bandung could have been much greater than what have been achieved. Yet, the potential has yet to be realized optimally for some reasons, one of which is the fact that the BCCF as well as other creative economy communities have yet to made contribution as expected. This is proven by the data and information that have been gathered, for example, the data on the achievement of creative city indicators of Bandung as follows:

Table 1.1

Creative City Parameters Achievement

\begin{tabular}{llccc}
\hline No & \multicolumn{1}{c}{ Indicators } & Score & $\mathbf{\%}$ & Grades \\
\hline & Recent earnings from sub-sector within the last & & & \\
1 & five years & 7 & 70.00 & Advanced \\
2 & Events organized & 4 & 40.00 & Poor \\
3 & Related educational institutions & 8 & 80.00 & Advanced \\
4 & Creative space available & 5 & 50.00 & Average \\
& Facilities provided for conducting creative & & & \\
5 & activities & 5 & 50.00 & Average \\
6 & City programmes & 7 & 70.00 & Advanced
\end{tabular}




\begin{tabular}{rllll}
7 & Sustaining government policy & 7 & 70.00 & Advanced \\
8 & Promoting activities & 6 & 60.00 & Average \\
9 & City cooperation & 6 & 60.00 & Average \\
10 & Ongoing networking facilitation & 6 & 60.00 & Average \\
& & \multicolumn{2}{c}{10} & \\
\hline
\end{tabular}

Source: Economic Department of the Regional Secretariat of Bandung City, 2015

The table above clearly indicates that the achievement of the indicator event organized scored 4 and fell under the "poor" grade. This can be interpreted as a factual problem as this indicator is related to the existence of creative economy communities that have yet to realize their creative economy activities optimally. This was justified by the data regarding creative activities held in the City of Bandung over the last five years as follows.

\section{Figure 1.1}

Creative Activities Held in the City of Bandung over the Period 2013-2017

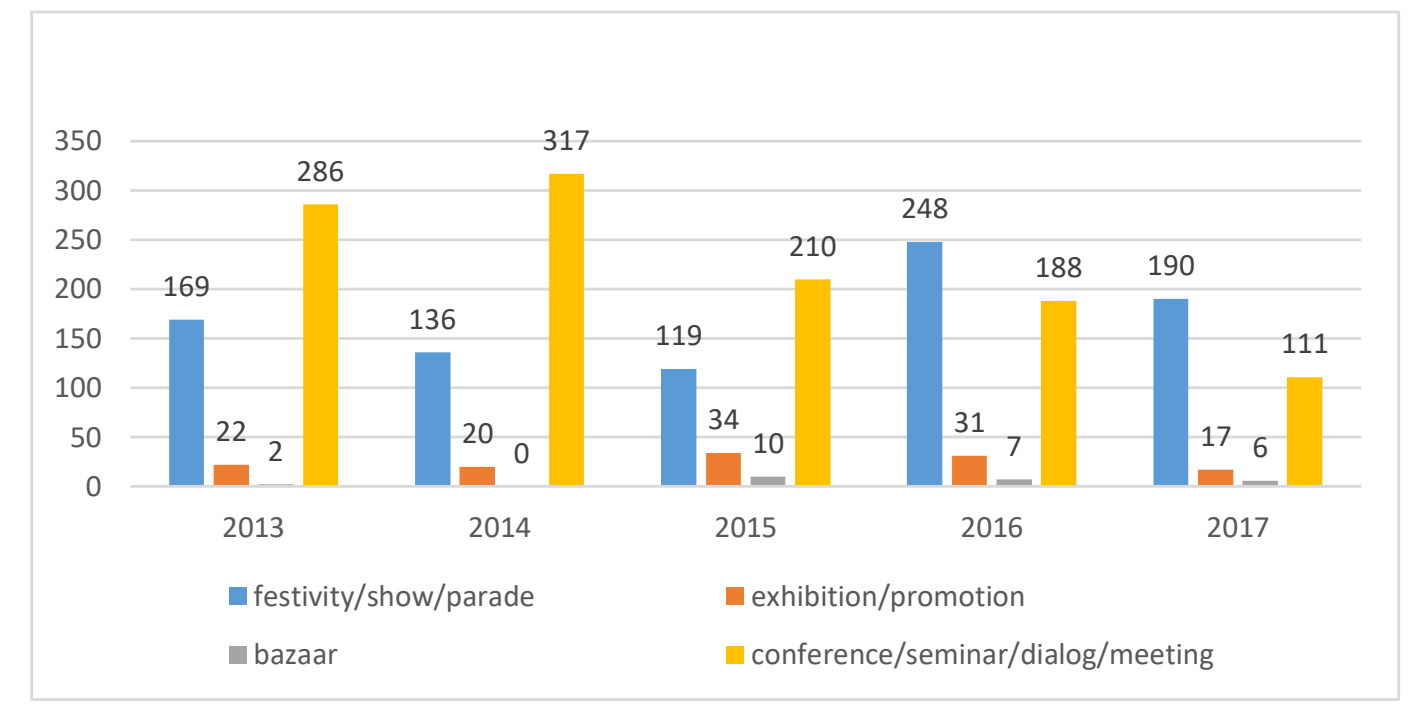

Source: Capital city police of Bandung, 2018

The figure above indicates four types of creative events in the City of Bandung, namely 1) festivity/show/parade event, 2) exhibition/promotion event, 3) bazaar event and 4) seminar/meeting event. The four types of events showed a declining trend each year despite some rise in particular events in particular years. In 2014, the number of seminar/meeting events peaked but later declined constantly. The number of festivity/show/parade events increased in 2006, yet decreased in 2017. Meanwhile, the number of exhibition/promotion events rose in 2015 but dropped in the next two years. The figure above reflects the activities the BCCF has conducted. Over two periods of BCCF leadership, some decreases in the activities occurred due to a number of issues. 
The factual problems revealed above implies that the interferences exercised by the BCCF in the development of creative economy in the City of Bandung have yet to be effective. Thus, this research was conducted with the aim of analyzing the interferences made by the BCCF as a representative of creative economy communities in the development of creative economy in the City of Bandung.

\section{Methods}

This research used the post-positivist approach as it employed the flow of thinking from the deductive to inductive oncoming and theories as its guidance to collect and analyze data. In the present research, theories were merely used as a guidance to give this research focus and direction, and there was no requirement to prove the theories or to obtain results matching with the theories. This research was descriptive research which provides description of some theories in order to establish an overall framework that serves as a guide throughout the research process. The society-political governance concept by Kooiman $(1993,2003)$ became the focus of this research, with interaction being its variable and interferences being its sub-variable.

For the purpose of collecting data for this research, in-depth interviews were conducted with several informants engaged in the creative economy development in the City of Bandung. The research exercises technique of purposive sampling since it engages identifying and selecting individuals or communities which are particularly well-informed or well-grounded with a phenomenon of interest (Cresswell and Clark, 2011). As in the table below,

\section{Tabel 1.2}

\section{List of Informants}

\begin{tabular}{|c|c|c|}
\hline No & Name & Position \\
\hline 1 & Ms. Ramalis & The Expert in Indonesia Creative Economy Board \\
\hline 2 & Mr. Taufik Hidayat & $\begin{array}{l}\text { The Secretary of Potencial and Competitiveness Department of The } \\
\text { Economic Division the City of Bandung }\end{array}$ \\
\hline 3 & Ms. Tris Avianti & $\begin{array}{l}\text { The Head of Creative Economy Departement in Cultural and } \\
\text { Tourism Office The City of Bandung }\end{array}$ \\
\hline 4 & Mr. Hadi & $\begin{array}{l}\text { The Secretary of Facility and Infrastructure Section of Creative } \\
\text { Economy Departement, Cultural and Tourism Office The City of } \\
\text { Bandung }\end{array}$ \\
\hline 4 & Ms.Dwinita Larasati & The Head of the Bandung City Creative Economy Committee \\
\hline 5 & Mr Harris Sugiharto & The Chairman of Indonesian Young Entrepreneurs Association The \\
\hline
\end{tabular}


City of Bandung

6 Ms. Tita Larasati

The Chairman of Bandung Creative City Forum (BCCF) 2017-2021

Source: Processed by the researcher, 2018

In addition, we gathered data from some literature or certain documents based on needs. Document studies were conducted by accessing documents like dissertations, theses, research reports and other textbooks as well as official documents like statistical reports, yearly reports and other relevant official documents, particularly The Blueprint of Creative Economy: Indonesia's New Power Towards 2025 planned by Ministry of Tourism and Creative Economy (2014), Implementation Evaluation Summary of Bandung as a Creative City written The Agency of Planning, Research, and Development of Bandung City (2015), The Report on The Accountability Statement of the Bandung Mayor (2016), The Report of Fundamental Riset Progress arranged by Satari and Assad (2017), and the official website retrieved from https://o2indonesia.wordpress.com (2017).

\section{Results and Discussion}

One way to develop creative economy in the City of Bandung, principally, is by promoting citizens' highly creative initiatives in governing themselves to design creative economy activities, and the BCCF has done just that since its founding to date. The Head of Creative Economy Division of the Office of Culture and Tourism of the City of Bandung once stated in an interview (May 12, 2018),

"The creative economy development has been started and initiated by BCCF-accommodated communities of the City of Bandung. As we all know, the momentum of creative economy development movement was in 2007, as at that time, the City of Bandung was appointed the pilot project of creative cities in the Greater East Asia. A year later, the BCCF was established."

The statement above obviously reveals that the BCCF has an advantage over other creative economy communities, in that the BCCF as a societal entity was the first one that developed creative economy in the City of Bandung. To this point of time, the BCCF is known as an entity that has successfully revamped and improved the City of Bandung. This has put the BCCF under the spotlight as it has time and again been requested to be a pioneer 
that propels creative economy activities in the City of Bandung. Given such capacity and experience, the BCCF has been asked to lend some ministries a hand with regard to the development of creative economy of some other regions at the national and regional level. Hence, it is only natural if the BCCF is showered with appreciation from the central government to regional government as well as other related parties thanks to its role and contribution in the development of creative economy.

As a non-profit organization, the BCCF serves as an organization that operates across different creative communities in the City of Bandung and functions as a hub, meaning that it helps bridge and provide facility for individuals, communities and citizens in the City of Bandung in creative activities for the purpose of creating prototypes of solution for the city's problems. As an official organization, the BCCF becomes an independent organization with vision, missions and goal. The BCCF's vision is to become a communication, coordination and business forum for companies, business entities or creative communities in Bandung. Meanwhile, the BCCF's missions are

a) to increase the driving force for the development and empowerment of creativity potentials of the citizens of Bandung and adjoining areas,

b) to introduce Bandung as a leading creative city at the regional, national and international levels,

c) to establish cooperation both on the national and international scales for the purpose of developing and building creative economy and industries in Bandung,

d) to enhance creativity as an effort to empower the economy in order to improve the quality of life of civil community, the ecosystem preservation and the acknowledgement of cultural diversity.

In the beginning, the BCCF lacked hierarchical organizational structure. However, ever since being legalized, it has a hierarchical organizational structure. Despite the hierarchy, all BCCF members have equal position and rights to express their ideas. The wide range of abilities, skills, insights and experiences of every member are valuable for building a strong synergy between members. They can complement each other, marked with members that constantly dedicate their time, labor, mind and wealth into all BCCF activities. From the onset, the BCCF has liven up the jargon "Hidup adalah Udunan" as a manifestation 
of gotong royong (mutual cooperation) and solidarity values among members as well as high spirit of militancy in every activity.

In conducting each of its activities, the BCCF applies the urban acupuncture and design thinking approaches. Urban acupuncture is a philosophical approach used by the BCCF in dealing with social and environmental issues in the city on a small scale, yet in a massive, continuous and effective way, so it is expected to be able to leave a positive impact on, and generate good quality for, the lives of the city and the citizens (the Head of the BCCF in an interview, May 12, 2018). Meanwhile, design thinking consists of observing and understanding, reframing, ideation, prototyping and co-design processes, focused on discussing innovation solutions for various urban issues on the basis of cooperation between stakeholders (Hendra in o2Indonesia.wordpress.com, 2013). These approaches are deemed as the most fun for, and easily understood by, every layer of the community as the community will have a greater freedom to think as creatively as possible without any restriction of any conventional matter (the Head of BCCF in an interview, May 12, 2018).

This research will further outline and analyze every indicator of the interferences made by the BCCF as an independent social entity in developing creative economy in the City of Bandung.

\subsection{Regular Meeting and Discussion on Social Issues}

Meeting up and communication with fellow organization actors constitute the first and fundamental indicator in this interaction. The meeting and communication conducted are not too formal and are intended as part of an effort to actualize themselves for them to obtain new information, insights and experiences. In principle, the process of mutual sharing, exchange, interpretation, learning and information collection taking place within the organization serve as the key to the success of the first indicator of interferences. It is worth noting that information constantly changes and develops in a rapid way, leading to the requirement for the response of the organization actors to understand the organization's dynamic internal conditions and uncertain external environment at all time.

It can be said that members of the BCCF network are basically creative despite zero support from the government. Their creativity flourishes as they like to ngumpul (gather), nongkrong (hang out) and ngobrol (chat). Through these activities, they find compatibilities between them in terms of hobby, aspirations or economic matters (the Mayor of the City of 
Bandung in medcom.id, August 18, 2017). Members of BCCF network comes from diverse backgrounds, either professionally or academically, which bear relevance with creative economy sub-sectors, such as design, fine art, architecture, music, fashion, craftsmanship, culinary, among others. It is necessary for these creative communities to expand their communications with other creative communities or community members to achieve a greater goal. Through the $\mathrm{BCCF}$, the communication and information exchange process can be facilitated. The existing creative fields are related to one another, thus the network established will support their creative activities.

In order to promote these communications and information exchange, the BCCF holds a discussion on a regular basis weekly or biweekly on Wednesday nights named "Rabuan." Rabuan is a meeting between members and citizens, in which different communities and entities share ideas to align their minds. However, different options emerge, and despite being aimed for good purpose, such differences sometimes trigger debates on a particular issue. From the beginning, the actors involved in the activities are strongly committed to the improvement and development of Bandung so as to achieve betterment of the lives of the city and citizens. The Chairman of the BCCF stated in an interview (March 28, 2018),

"....Rabuan is an example of positive hang-out, in which different elements, such as university students, communities, activists and whatnot meet. Rabuan is a community gathering, thus the attendants are allowed to share, make announcements, raise particular issues, and more. This is an activity that has been held by the BCCF biweekly since long time ago, but there are some days off, for example on feast days or long holidays. Yet, when it is necessary or nearing a big event, the gathering can be held once in a week."

In addition to Rabuan, the BCCF also holds Jorowok.bdg as its way to express ideas or thoughts regarding creative economy development in the City of Bandung. The themes raised include A New Bridge between Bandung and Creative Economy Body, Managing Bandung: Innovation, Decentralization, Collaboration, Bandung Design Nation: Carving Creative Spaces and City Hall the Pulse of the City of Bandung. This is in line with the statement of the Chairmen of the BCCF in an interview (March 28, 2018),

"We also have jorowok.bdg with speakers coming from the outside of this community. They are national and regional figures, for example, Gita Wiryawan, Mari E. Pangestu, Anindya 
Bakri, Dedi Mizwar, Dedy Iskan, Triawan Munaf, Ridwan Kamil, Pidi Baiq, Isran Noor, Imam Nahrawi and whoever have the expertise relevant with a given issue. We just have unbiased talks. But we have not held Jorowok for a long time because we fear it would be politicized."

Jorowok.bdg is basically a positive event for the BCCF as well as other creative economy communities, especially figures with influences at the national and regional levels. In this thought sharing moment, they are expected to agree with a conclusion which will be followed up with concrete actions for the development of creative economy, especially in the City of Bandung. Nevertheless, this event did not last for long as the BCCF asserted that it is a social organization that is neutral from any form of political influences and interventions. It intended to avoid any talk and opinion of creative economy communities and citizens that the $\mathrm{BCCF}$ is directed, compromised and politicized by such figures for temporary interests of theirs. For this reason, the BCCF ultimately decided that they would only involve academics, experts and practitioners in the field of creative economy in their meetings and discussions.

\subsection{Leader Motivation on His Members}

A leader in a social organization like the BCCF beyond question occupies the central position as an influential person who moves people around him. It is necessary for a leader to motivate his followers on the basis that this organization is filled by civil people who voluntarily engage in an active participation in, and contribute to, the social organization with different motifs. Such voluntary service based on diverse motifs subsequently puts responsibility on the organization leader to preserve and live up his followers' motivation.

In its tenth year of running, the BCCF as a social organization is facing a strikingly different condition compared with the condition it faced early in their establishment. The most utterly different condition is evident in its members' spirit to actively contribute to the development and promotion of creative economy of the city. In the first period after the founding of the BCCF, its members and networks had high idealism and militancy in conducting various activities. It even created a well-known jargon, namely "Hidup adalah Udunan", as a form of mutual cooperation spirit in helping build the organization's resources for the sake of achieving their major goals. Back then, their number one motivation was to improve the environmental conditions of the City of Bandung they 
deemed as having been neglected by the government. Thus, with various backgrounds, abilities and experiences it possessed, it sought to create a number of solution prototypes for the issues faced by the city.

In the second and third periods, the BCCF sought to adjust the motivation previously given as the conditions and challenge they faced were different. In the second period, the BCCF opened a way for its members and networks to show up before the public and become popular thanks to their influences. Especially with the massive support from various social media back then, they were facilitated to introduce themselves through various activities. The Chairman of the BCCF stated in an interview (March 28, 2018),

"The character of the BCCF is actually in the midst of experiencing a change. It was filled with activities that required militants and idealists who worked without any incentives and rewards. It is different today when it is compared to it was ten years ago, so we must increase the motivation in a different way. So, to raise their motivation, we do things like asking particular communities to raise up-to-date issues. Just think about it, youths nowadays need to have a presence and become people with influence. That is what matters."

Unlike previous periods, in the third period, the BCCF encountered internal and external challenges that were far more complex. One of the most crucial matters was the funding for various activities, in that there was no way it would keep on relying on the fund contribution from its members and networks. This was especially the case as at this time, their members started to think realistically about their own needs, making their motivation change into fulfilling their needs while they were still active in the BCCF. At least the activities they conducted during this period did not burden their finance anymore. For this reason, the $\mathrm{BCCF}$ at this time is directed toward activities relating to social enterprise. It commercializes its services to support its managers and organization. In other words, the profits gained are allocated for personal and social interests. In this way, it is expected that the programs or activities to be performed will no longer be hindered, or in other words, they will be assisted in terms of finance.

\subsection{Capability of Organizing and Designing Activities}

One of the biggest concerns about an independent social organization is its ability to demonstrate its identity autonomously. This is related to what they can do or produce, be it producing goods, providing services or organizing activities. With such independence, there 
will be coherent internal interaction among its members. It will seek to manage and take care of different things in such a way, starting from the simplest extreme to the most complex one, that it achieves its fundamental goals, for example the determination of the structure, actors, performers, how to perform, relationship between one function and another, shared commitment, communication between actors, among others.

Ever since its establishment, the BCCF as an independent social organization has held more than 250 programs and activities. All of the programs and activities were based on what it calls urban acupuncture and design thinking, which constitute its effort to generate various solution prototypes for the problems faced by the City of Bandung (Larasati in the South East Asian Creative Cities Forum presentation, December 8-9 December, 2016). So far, the BCCF as a hub organization that accommodates assorted creative communities is still focused on the organization of various creative economy programs and events. This has been ongoing in two BCCF leadership periods, namely Ridwan Kamil's era (2008-2013) and Fiki Satari's era (2013-2018). Currently, the BCCF is transitioning to the third leadership period (2018-2023) under Dwinita Larasati and is still in the process of establishing a new structure and formulating missions and work programs.

In Ridwan Kamil's era, the BCCF conducted a large number of creative activities and improvements of urban infrastructure as a support for the creative economy development. The Chairman of the BCCF stated in an interview (2018),

"In the first period when Ridwan Kamil served as the chairman of the BCCF, we had a considerable number of activities. We provided examples, like solution prototypes for problems, whatever they were, for example, green open space, urban park, public space and public art. Whatever they were, we promoted them as prototypes on the city scale."

As the first chairman of the BCCF (2008-2013), Ridwan Kamil introduced three programs (Ridwan Kamil in Fitriyana, 2013: 3) as a form of service for Bandung citizens in general and creative communities in particular, including the following:

1. Preserving creative culture: community organization, events, media, and education.

2. Maintaining creative business or entrepreneurs: Business incubators, networking, economic policy, taskforce or creative economy council.

3. Creating responsive city Planning or design: creative clusters, public space, district regeneration, architecture. 
Meanwhile, under the leadership of Fiki Satari as the second chairman of the BCCF (2013-2018), the BCCF's role was more focused on the city's human resource reinforcement although some excellent programs from the previous period were carried on. The BCCF considered that Bandung citizens experienced a shock therapy when finding out that their city had been transformed into a creative city, showing that they actually were not ready to face the fact. This was apparent in their behaviors and habits that leaned toward vandalism involving damage of the city's built facilities and infrastructure. The Chairman of the BCCF stated in an interview (March 28, 2018),

“...In Fiki's era, the BCCF's role was forced to change. We were more concerned with the human resources as before the advent of the BCCF, it can be said that Bandung was neglected for a decade. The citizens were used to conditions that, in fact, were sub-standard. It was proven with them littering when beautiful parks were built. And when they were provided with sidewalks, they used them as their place for selling things. So, the human resources were not ready."

Accordingly, the BCCF under Fiki Satari's command had four major programs, three of which were 2015 Helar Festival, Simpul Institute and Kampung Kreatif, which were organized independently by the BCCF and other creative communities, while another program, Design Action Bandung, was a collaborative program. First, the 2015 Helarfest was the continuation of the previous Helarfest program, and will be held again in the future. It can be said that this program is one of the historical footprints left during the birth of the BCCF. The 2015 Helarfest coincided with the 60 th Asia-Africa Conference, and this momentum was well utilized by the BCCF to gather all creative economy communities and networks in the City of Bandung. They all were engaged as the 2015 Helarfest accommodated various events, such as exhibitions, concerts, workshops, performance arts, among others, and were facilitated to display their creative economy works and products (jabarprov.go.id, January 30 2015).

Second, Kampung Kreatif was a follow-up from 2012. At that time, the BCCF invited some regions in the City of Bandung to foster some creativity potentials by carrying out the 2012 Kampung Kreatif program. This program was based on the fact that the majority of Bandung people lived in kampong, so they were stakeholders that had to be engaged and whose aspirations and needs must be fulfilled. For this purpose, this Kampung Kreatif 
program was carried out to benefit the people's economy. The people were required to be independent in using their creativity potentials in the arts and tourism sectors. Hence, the economic activity that could be performed in this Kampung Kreatif program was creative tourism activity. If this could be realized, it could be ascertained that it would result in job opportunity expansion, equitable distribution of local people's income, improvement of added values of the products produced on the local culture basis, domestic product market expansion, among others.

The third program was Simpul Institute. Simpul Institute was designed based on the need for, and importance of, education of Bandung citizens. This program is believed to be a foundation and lighter for the creativity sustainability of the citizens and communities in the City of Bandung. The Simpul Institute program is the manifestation of the BCCF's aspiration to accommodate the wish of different creative communities of the City of Bandung to gather, interact, discuss and share knowledge with each other, to conduct activities, such as trainings, workshops, courses, and excursions, and above all, to improve the capacity and networking of creative actors in the City of Bandung.

\subsection{Driving Social Movements}

The power of social movement actions will always be obvious in every societal organization. This movement action is the right example of interferences, which is spontaneous, liquid, relatively free and not too formal in nature. This is later called the character of participatory interaction, which basically is founded on its responsiveness as an object governed and managed (system to be governed) to government entities that have full authorities and powers (governing system). The form of such response can be seen in demonstration actions, writing on media, audience and other activities that show a form of protest. The participation in such social movement activities is a simple example of what is referred to as rationality-based collective actions to struggle to uphold the truth, realize prosperity and fight against all negative and deviant attitudes and actions.

The BCCF, a social organization with members who have various diverse backgrounds, has its own way to take social movement actions. We observed that it takes the actions in a fairly soft way, namely intellectual way. To put it simply, this intellectual way can be understood as a way that uses academic aspects, namely using and applying theories and scientific data, as opposed to political, opportunistic or even repressive aspects. 
This can be seen in every activity that applied the urban acupuncture and design thinking principles. These two principles guide the members and networks of the BCCF to express and voice out all of their aspirations and needs. They created various solution prototypes for the problems faced by their city without having to involve themselves with the government. It was not until the solution prototypes were successfully implemented that they exposed, disseminated and raised them to some media, from which the government subsequently gained awareness of, and recognized, what its citizens wanted. From where we stand, this is one of the most intellectual and elegant ways to remind and even correct the attitudes and actions of the government that are incorrect and even deviant.

Another way the BCCF criticized, and protested against, the government was having some writings posted on several media. This was done by the BCCF to let the general public know the actual conditions of the City of Bandung. Ultimately, this power of media is expected to be able to move the city government along with its networks to do something in line with their responsibilities and functions.

Finally, this research regarded that the four interferences indicators abovementioned are crucial and fundamental forms of activism for the existence of the BCCF as an independent social entity. The various activities that have long been conducted by the BCCF have enhanced the BCCF's reputation because of the positive recognition and appreciation it received from different parties. This research also pointed out a fairly fundamental change, in that the BCCF slowly changed its activities due to the shift in the motivation of its managers and community members. Currently, the BCCF's activities are directed toward social enterprise, with which it will commercialize its services to support its managers and organization. In other words, the profits that they gained will be allocated for personal and social interests. In this way, it is expected that the programs or activities to be performed will no longer be hindered, or in other words, they will be assisted in terms of finance.

Nevertheless, some worries remain exist due to the fact that the BCCF's focus is slowly shifting into private purpose. This will certainly lead to a change in the mindset and attitudes of the managers and members in conducting their activities, which will tend to prioritize business interests over social interests. This was in contrast to the BCCF's aim in its founding to merely be a social entity that is able to accommodate the creativity power of its citizens to provide solutions for the problems of theirs and the city. This should be taken 
into consideration by current BCCF management in governing and developing the organization to maintain, or even enhance, the already-good reputation.

\section{Conclusions}

Based on the findings from the field, the BCCF is the prime example that represents the existence of such creative economy communities. The BCCF is present as an independent societal organization that is concerned with the development of creative economy through a number of internal and external activities. To the BCCF, the activities are the real manifestation of its identity that has a considerable capacity potential. This identity upholds the urban acupuncture and design thinking principles, based on which the BCCF revamps and improves the city by creating some urban solution prototypes. As such, up until now, they are able to leave physical and social traces that can be felt by the citizens and the city. However, while the BCCF has successfully made outstanding achievements, it is faced with a reality that it has changed. Thus, into the new management, the BCCF strives to adapt to their needs at the present time while carrying on its previous positive activities, especially those directly associated with Bandung citizens.

\section{References}

Bernauer, T., Betzold, C (2012). Civil Society In Global Environmental Governance. SAGE Publication. 21(1) pp. 62-66.

Chhotray, V., Stoker, G. (2009). Governance Theory and Practice: A Cross-Disciplinary Approach. Basingstoke, UK: Palgrave Macmillan.

Cresswell, J.W, Plano Clark, V. (2007). Designing and Conductiong Mixed Method Research. Thousand Oaks, CA: SAGE

Jessop, B. (1997). The Governance of Complexity and the Complexity of Governance: Preliminary

Remarks on Some Problems and Limits of Economic Guidance. in AshAmin and Jerzy Hausner.(1997). Beyond Market and Hierarchy: Interactive Governance and Social Complexity. Lyme, U.S.: Edward Elgar. pp.95-128.

Kooiman, J (ed.). (1993). Modern Governance: Government-Society Interactions. London: SAGE Publication Ltd. 
Kooiman, J. (2002). Governance. A Social-Political Perspective, in Grote, Jurgen., \& Gbikpi, Bernard (Eds): Particiatory Governance: Political and Societal Implications. Germany: Springer Fachmedien Wiesbaden

Kooiman, J. (2003). Governing as Governance. New Delhi: SAGE Publication Ltd

Lappe, F.M., \& Dubois, P.M. (1994). The quickening of America: Rebuilding our nation, remaking our lives. San Francisco: Jossey-Bass,Inc. Publishers.

Pierre, J (ed.). (2000). Debating Governance. Oxford University Press, pp. 138-166.

Pierre, J., Peters, B.G. (2005). Governing Complex Societies: Trajectories and Scenarios. New York: Palgrave Macmillan

Rosenau, J. (1992). Governance, Order, and Changes in World Politics. in Rosenau, J. and E. Czempiel. (1992). Governance without Government: Order and Change in World Politics. Cambridge University Press. pp. 1-29

Salomon, L. (ed). (2002). The Tools of Government: A Guide to the New Governance. Oxford University Press.

Satari, F.C dan Asad, N. (2017). Model Strategi Pengembangan Wirausaha E Ekonomi Kreatif Di Tingkat Kota (Pemetaan Per Kecamatan) Di Bandung, Dengan Pendekatan Ekosistem Ekonomi Kreatif, Swot, Identifikasi Peran (Pentahelix) Stakeholders Dan Rencana Aksi Implementasinya. Fakultas Ekonomi dan Bisnis: Universitas Padjadjaran.

Steen-Johnsen, K., Eynaud, P., Wijkstrom, F. (2011). On Civil Society Governance: An Emergent Research Field. Voluntas: International Journal of Voluntary and Nonprofit Organizations, 22 (4) pp. 555-565 Published by: Springer

Stoker, G. (1998). Governance As Theory: Five Propositions. Blackwell Publishers, pp. 17-28

\section{Regulations}

Presidential Instruction of Indonesia Republic Number 6 of 2009 on Creative Economy

Development

The Regional Regulation of Bandung City Number 3 of 2014 on Short-Term Regional Development Plan (RPJMD) of Bandung City for the period 2013-2018

\section{Official Documents}

Badan Perencanaan Pembangunan, Penelitian, dan Pengembangan Kota Bandung. 2015. Kegiatan Evaluasi Pelaksanaan Bandung Sebagai Kota Kreatif 
Badan Perencanaan Pembangunan, Penelitian, dan Pengembangan Kota Bandung. 2016. Laporan Keterangan Pertanggungjawaban Wali Kota Bandung 2016.

Kementerian Pariwisata dan Ekonomi Kreatif. (2014). Ekonomi Kreatif: Kekuatan Baru Indonesia Menuju 2025. RURU Corps (www.rurucorps.com)

\section{Official Websites}

https://en.unesco.org/creative-cities/home

https://www.medcom.id/cards/10498-kerja-bersama/yNLeVdyb-cerita-ridwan-kamilkembangkan-ekonomi-kreatif-di-bandung

Bisnis.com Jawa Barat. 2014. “Tantangan Metropolitan Bandung Mencegah Stagnasi $\begin{array}{llll}\text { Ekonomi Kreatif". } & \text { Acessed }\end{array}$ http://bandung.bisnis.com/read/20140925/82446/519060/mencegah-stagnasi-ekonomikreatif

Kompas.com. 2015. “UNESCO Masukkan Kota Bandung Dalam Jaringan Kota Kreatif.” Accessed December 12. https://regional.kompas.com/read/2015/12/12/12351701/UNESCO.Masukkan.Kota.Ban dung.dalam.Jaringan.Kota.Kreatif

Larasati, D. (2017, November 26). O2 Indonesia. (Web log). Retrieved from https://o2indonesia.wordpress.com/tag/event/

Portal.Bandung.go.id. "Workshop Design Action.BDG". Accessed September 30. https://portal.bandung.go.id/posts/2013/10/01/Wpom/workshop-design-actionbdg http://www.pikiran-rakyat.com/bandung-raya/2016/11/10/design-action-2016-hadirkansolusi-masalah-kota-bandung-384472 http://jabarprov.go.id/index.php/news/10793/Helarfest_2015_Harus_Tinggalkan_Tiga_Jejak https://kominfo.go.id/content/detail/5277/ekonomi-kreatif-adalah-pilar-perekonomian-masadepan/0/berita

https://ekbis.sindonews.com/read/606780/36/bccf-tumbuhkan-kreativitas-5-kampung-dibandung-1333683346 